\title{
Erwinia chrysanthemi: description of two new biovars (bv 8 and bv 9) isolated from kalanchoe and maize host plants
}

\author{
N Ngwira, R Samson \\ INRA, pathologie végétale, route de Saint-Clément, Beaucouzé, 49000 Angers, France
}

(Received 13 November 1989; accepted 29 January 1990)

\begin{abstract}
Summary - The bacterial phytopathogen Erwinia chrysanthemi may attack a wide spectrum of host plants. The species is officially divided into 6 pathovars on the basis of their host range. An alternative biovar classification which was based on biochemical criteria was proposed independently of pathogenicity (table I). Two new biovars are described in the present study. Biovar 8 contains 4 maize strains originating from India, France and the USA. Biovar 9 contains 3 kalanchoe strains from Denmark. France and Switzerland (table II). The 2 new biovars were found to differ from bvs 3 and 7 by the arginin dihydrolase test (table III). The validity of using the biovar system instead of the official pathovar classification for $E$ chrysanthemi is discussed. Particularly, it takes into account the diversity of the species that occurs in more than 50 host plants.
\end{abstract}

Erwinia chrysanthemi / maize / kalanchoe / biovar / identification

Résumé - Erwinia chrysanthemi, description de deux nouveaux biovars (bv8 et bv9) isolés des planteshôtes maïs et kalanchoe. La bactérie phytopathogène Erwinia chrysanthemi attaque une large gamme de planteshôtes. L'espèce est divisée officiellement en 6 pathovars sur la base de leur spectre d'hôtes. Une autre classification en biovars fut proposée, reposant sur des critères biochimiques (tableau l). Deux nouveaux biovars sont décrits dans cette étude. Le biovar 8 contient 4 souches de maïs provenant d'Inde, des Etats-Unis et de France, et le biovar 9 regroupe 3 souches de kalanchoe originaires du Danemark, de Suisse et de France (tableau II). Les 2 nouveaux biovars diffèrent des bvs 3 et 7 par le test arginine dihydrolase (tableau III). On y présente l'intérêt d'utiliser le système des biovars à la place de la classification actuelle d' E chrysanthemi en pathovars. En particulier, il permet de rendre compte de la diversité de cette espèce qui peut se trouver maintenant sur plus de cinquante plantes-hôtes.

\section{Erwinia chrysanthemi / mais / kalanchoe / biovar / identification}

\section{INTRODUCTION}

Erwinia chrysanthemi (Burkholder et al, 1953) is a phytopathogenic bacterium which induces softrot and wilting. The bacterium attacks a wide range of host-plants, and occurs in many areas of the world (Bradbury, 1984). In phytobacteriology, infra-subspecific epithets were chosen as "pathovars", terms currently used to designate organisms on the basis of their host range (Young et al, 1978). E chrysanthemi was first divided into 4 pathovars according to the host of origin: pv (pathovar) chrysanthemi from Chrysanthemum morifolium, pv dieffenbachiae from Dieffenbachia spp, pv parthenii from Parthenium argentatum and pv zeae from Zea mays. Then 2 more pathovars were added: $p v$ dianthicola from Dianthus sp and $\mathrm{pv}$ paradisiaca from Musa paradisiaca. The 6 pathovars are listed in the last Bergey's Manual of Systematic Bacteriology (Lelliott and Dickey, 1984) with the mention that "the relationship between pathogenicity, phenotypic properties and serological reactions of strains of the pathovars" is "not entirely clear".

Since strains of $E$ chrysanthemi have now been isolated from more than 50 plant species (Bradbury, 1984), it seems difficult to maintain the practice of naming the bacteria after the plant they come from. In the case of pathogenic differences between the isolates, host specificity seems difficult to prove (Dickey, 1981; Janse and Ruissen, 1988). However, physiological (biochemical) testing revealed differences between $E$ chrysanthemi strains (Hildebrand et al, 1978; Samson and Nassan-Agha, 1978; Dickey, 1979; Dickey and Victoria, 1980; Thomson et al, 1981). 
The biochemical differences have led to the classification into biovars (Samson et al, 1987) ie subdivisions of the bacterial species that could group all the strains showing the same biochemical profile. Seven biovars have been described using 10 biochemical tests (see table 1). The present study adds 2 more biovars to the Erwinia chrysanthemi biovar system.

\section{MATERIALS AND METHODS}

\section{Bacteria}

The bacteria were isolated from 2 host-plants: Kalanchoe blossfeldiana and Zea mays (see table II). The strains were cultivated on LPA slants (yeast extract 3 $\mathrm{g} / \mathrm{l}$, peptone $5 \mathrm{~g} / \mathrm{l}$, agar $15 \mathrm{~g} / \mathrm{l}$, without glucose) that could be kept several months. Stocks of the strains were procured by freeze-drying.

\section{Characterization}

The identity of the strains was established by the criteria adopted in Bergey's Manual (Lelliott and Dickey, 1984). The tests, performed according to Lelliott and Stead (1987) unless otherwise specified were: Gram reaction by $\mathrm{KOH}$ solubilization (Suslow et al, 1982), pectate degradation (Sutton's medium; modified by Bonnet, 1973), oxidation/fermentation of glucose in Hugh and Leifson medium, gas production from $d-$ glucose, starch hydrolysis, nitrate reduction, indole production from tryptophan, malonate utilization in
ARJ medium (Ayers et al, 1919) by indicator shift (bromothymol blue), and lecithin hydrolysis on egg yolk medium.

\section{Biovar criteria}

The criteria for biovar definition (Samson et al, 1987) were as follows: growth at $39^{\circ} \mathrm{C}$, anaerobic degradation of arginine (ADH) according to Moeller (1955), inulin assimilation in phenol red peptone water; other carbon sources were tested by acidification/ alkalinisation of ARJ liquid medium (bromothymol blue) mixed with $0.3 \%$ of the carbohydrate: $d(-$ Jarabinose, 5-ketogluconate, mannitol, melibiose, raffinose and $d(-)$ tartrate. Cis-aconitate was discarded because of the variability of the result for the same strain.

\section{API galleries}

Some criteria can be obtained by using API galleries (La Balme-les-Grottes, 38390 Montalieu Vercieu, France) such as arginine dihydrolase, indole, mannitol and melibiose from the API 20E, and $d(-)$ arabinose, 5-ketogluconate, inulin, mannitol, melibiose and raffinose from API 50CHE, provided a longer period of time is used than specified (4 to 6 days).

\section{RESULTS}

The strains tested were identified as $E$ chrysanthemi based on the negative Gram reaction, glu-

Table I. The 7 biovars of Erwinia chrysanthemi. According to Samson et al (1987): growth at $39{ }^{\circ} \mathrm{C}$; arginin dihydrolase activity in Moeller's medium; acidificaton or alkalinisation of $d(-)$ arabinose, 5-ketogluconate, inulin, mannitol, melibiose, raffinose and $d(-)$ tartrate in mineral basal medium.

\begin{tabular}{|c|c|c|c|c|c|c|c|c|c|}
\hline Biovars & $39^{\circ} \mathrm{C}$ & $A D H$ & $\begin{array}{c}\text { d-arabi- } \\
\text { nose }\end{array}$ & $\begin{array}{l}5 \text { ketoglu- } \\
\text { conate }\end{array}$ & inulin & mannitol & melibose & raffinose & $\underset{\text { tartrate }}{\mathrm{d}-}$ \\
\hline bv1 & - & + & - & - & + & + & + & + & + \\
\hline bv2 & + & - & + & - & - & + & - & - & - \\
\hline bv3 & + & - & + & - & - & + & + & + & - \\
\hline bv4 & + & - & + & + & - & - & + & + & + \\
\hline bv5 & + & + & - & - & + & + & + & + & - \\
\hline bv6 & + & - & - & - & - & + & + & + & - \\
\hline bv7 & - & + & - & - & + & + & - & - & + \\
\hline
\end{tabular}


Table II. Origin of the bacteria. a: CFBP (French Collection of Phytopathogenic Bacteria), INRA Angers, France; b: National Collection of Plant Pathogenic Bacteria, ADAS Harpenden, Great Britain.

\begin{tabular}{cllllc}
\hline Strain No & Host plant & Yrof isolation & Country & Author's No & NCPPB equivalent ${ }^{b}$ \\
\hline 1447 & Zea mays & 1969 & India & Payak (17) & 2546 \\
1528 & Zea mays & 1966 & USA & Kelman (W3.20/SR80) & 2541 \\
1531 & Zea mays & 1966 & USA & Kelman (W1.1/SR62) & - \\
1596 & Zea mays & 1974 & France & Samson (237-3) & - \\
1805 & $\begin{array}{l}\text { Kalanchoe } \\
\text { blossfeldiana }\end{array}$ & 1977 & Denmark & Dinesen (EK II) & - \\
2598 & $\begin{array}{l}\text { Kalanchoe } \\
\text { blossfeldiana }\end{array}$ & 1985 & Switzerland & Grimm (531) & - \\
2982 & $\begin{array}{l}\text { Kalanchoe } \\
\text { blossfeldiana }\end{array}$ & 1988 & France & Samson (SH 170-1) & - \\
& & & & & \\
\hline
\end{tabular}

cose fermentation, nitrate reduction, Sutton polypectate acidification and liquefaction, no starch hydrolysis, gas production from $d$-glucose, indole production from tryptophan, malonate alkalinization and lecithin hydrolysis.

When the biovar criteria were examined, none of the strains studied corresponded to any of the 7 previously described biovars. The 4 Zea mays strains, which show the same new profile, are grouped in the biovar 8 category, while the Kalanchoe strains, displaying other common characteristics, are contained in the biovar 9 (see table III).

\section{DISCUSSION}

Two new biovars that differ from the 7 previously described biovars were found. They differed only in the ADH test. Biovar 8 is a biovar 3 that could be ADH positive, and biovar 9 is a biovar 7 that appears to react as ADH negative. However, the $\mathrm{ADH}$ test must not be considered as a variable test. When it is performed according to Moeller (1955), ie in the presence of $0.05 \%$ glucose (which allows better growth) and pyridoxal phosphate (which promotes the decarboxylase activity), the results are consistent for a given strain. This method was successfully applied to some Erwinia by Zherebilo and Gvozdyak (1976). It proved to be more sensitive in our laboratory for fermentative bacteria than Thornley's test (1960).

To allow comparisons between laboratories, we would recommend the use of previously described methods. We also designate reference strains for the new biovars: CFBP 1447 (NCPPB 2546) for bv8, and CFBP 1805 (Dinesen EKI) for bv9.

Table III. Description of biovars 8 and 9. T: the strains 1447 and 1805 are chosen as references for the new biovars, bv8 and bv9, respectively.

Biovars Strain No $39^{\circ} \mathrm{C} A D H$ d-Arabinose 5 ketogluconate Inulin Mannitol Melibiose Raffinose d-Tartrate

\begin{tabular}{|c|c|c|c|c|c|c|c|c|c|c|}
\hline bv8 & $\begin{array}{l}1447^{\top} \\
1528 \\
1531 \\
1596\end{array}$ & + & + & + & - & - & + & + & + & - \\
\hline bv9 & $\begin{array}{l}1805^{\top} \\
2598 \\
2982\end{array}$ & - & - & - & - & + & + & - & - & + \\
\hline
\end{tabular}


The classification of the kalanchoe strains into a new biovar is consistent with the results of Dinesen (1979) who described his strains pathogenic to kalanchoe as defined by $A D H$, melibiose, raffinose and $d(-)$ arabinose negative tests. He concluded that the strains he tested did not fit in the 3 biovars known at that time. Similarly, Janse and Ruissen (1988), applying the biovar system to classify the $E$ chrysanthemi isolated from the Netherlands, found that their own kalanchoe isolates could belong to biovar 7 , but with a negative ADH. It thus seems that the creation of biovar 9 is enhanced.

The question of relationships between host plants and biovars has again arisen. The majority of the maize strains studied belong to either biovar 3 (Samson and Nassan-Agha, 1978; Dickey, 1979 whose subdivision IV is equivalent to bv3), or to biovar 8 (this study). But biovar 3 is not restricted to maize strains, since it harbours isolates from many other plants: Aechmea sp, Aglaonema, Ananas, Chrysanthemum morifolium, Cyclamen, Dieffenbachia, Dracoena, Euphorbia sp, Ipomae sp, Musa sp, Pelargonium, Phalaenopsis, Philodendron, Saintpaulia, Syngonium. Biovar 9 was created for the 3 kalanchoe strains studied. The fact that these strains were from different origins, such as Denmark, Switzerland and France, leads us to hypothesize that biovar 9 could be linked to the host of origin. However, one Dianthus $\mathrm{sp}$ strain from the Netherlands may belong to the same biovar (Janse and Ruissen, 1988).

In fact, with 9 criteria that may be plus or minus, one could mathematically expect $2^{9}=$ 512 combinations. Up to now, 9 biovars have been discovered. It seems evident that if other biovars were found in nature, they would probably be less numerous than 512 . The biovar system is therefore proposed to classify $E$ chrysanthemi isolates independently of their host. In the case of biochemical differences being detected between the strains, it only means that the strains are "biochemical variants". The taxonomic value of such variants must be estimated on wide collections of bacteria. Such a need was expressed during an EPPO conference held in 1985 in Wageningen, on "the new diagnostic technics in plant protection". The biovar distribution would give a biological structure to the diversity of this bacterial species. In the Netherlands, 41 strains were found to belong to 3 biovars (Janse and Ruissen, 1988). In our laboratory, a study of almost 200 strains is being carried out isolated from 27 host plants and originating from
5 continents (Samson et al, 19.90). The aim is to confirm the respective weight of each biovar, in order to propose a true taxonomical subdivision of $E$ chrysanthemi species instead of the confusing pathovar classification.

\section{ACKNOWLEDGMENTS}

We thank 1 Dinesen and R Grimm for kindly sending us the E chrysanthemi strains.

\section{REFERENCES}

Ayers SH, Rupp P, Johnson WT (1919) A study of the alkali forming bacteria. Milk USDA Bull 782

Bonnet P (1973) Les Enwinia pectinolytiques. I. Diagnostic biochimique rapide. Ann Phytopathol 5, 355376

Bradbury JF (1984) Guide to Plant Pathogenic Bacteria. $C A B$ International Mycological Institute, Kew, 72-76

Burkholder WH, Mc Fadden LH, Dimock AW (1953) A bacterial blight of chrysanthemums. Phytopathology 43, 522-525

Dickey RS (1979) Erwinia chrysanthemi: a comparative study of phenotypic properties of strains from several hosts and other Erwinia species. Phytopathology 69, 324-329

Dickey RS (1981) Erwinia chrysanthemi: reaction of 8 plant to strains from several hosts and to strains of other Erwinia species. Phytopathology 71, 23-29

Dickey RS, Victoria Jl (1980) Taxonomy and amended description of strains of Erwinia isolated from Musa paradisiaca Linnaeus. Int J Syst Bacterio/ 30, 129134

Dinesen IG (1979) A disease of Kalanchoë blossfeldiana caused by Erwinia chrysanthemi. Phytopathology $Z 95,59-64$

Dye DW, Bradbury JF, Goto M, Hayward AC, Lelliott RA, Schroth MN (1980) International standards for naming pathovars of phytopathogenic bacteria and a list of pathovar names and pathotype strains. Rev Plant Pathol 59, 153-167

Hildebrand DC, Schroth MN, Thomson SV (1978) Nutritional Properties Useful for Identification of SoftRotting Erwinia species. Proc 4th Int Conf Plant Pathogenic Bacteria, Angers, 561-562

Janse JD, Ruissen MA (1988) Characterization and classification of Erwinia chrysanthemi strains from several hosts in the Netherlands. Phytopathology 78, 800-808

Lelliott RA, Dickey RS (1984) Genus VII: Erwinia. Bergey's Manual of Systematic Bacteriology (Krieg NR, ed) Williams and Wilkins, Baltimore, 471 
Lelliott RA, Stead DE (1987) Methods for the Diagnosis of Bacterial Diseases of Plants (Preece TF, ed) Blackwell Scientific Publications, Oxford

Moeller V (1955) Manuel des Techniques Bactériologiques (Buttiaux R, Beerens $H$, Tacquet $A$, eds) Flammarion, Paris, 302 pp

Samson R, Nassan-Agha N (1978) Biovars and Serovars Among 129 Strains of Erwinia chrysanthemi. Proc 4th Int Conf Plant Pathogenic Bacteria, Angers, 547-553

Samson R, Ngwira N, Rivera N (1990) Biochemical and Serological Diversity of Erwinia chrysanthemi. Proc 7 th Int Conf Plant Pathogenic Bacteria, Budapest

Samson R, Poutier F, Sailly M, Jouan B (1987) Caractérisation des Erwinia chrysanthemi isolées de Solanum tuberosum et d'autres plantes-hôtes selon les biovars et sérogroupes. Bull OEPP, EPPO Bull 17, $11-16$
Suslow TV, Schroth MN, Isaka M (1982) Application of a rapid method for Gram differentiation of plant pathogenic and saprophytic bacteria without staining. Phytopathology 72, 917-918

Thomson SV, Hildebrand DC, Schroth MN (1981) Identification and nutritional differentiation of the Erwinia sugar beet pathogen from members of Erwinia carotovora and Erwinia chrysanthemi. Phytopathology 71, 1037-1042

Thornley MJ (1960) The differentiation of Pseudomonas from other Gram-negative bacteria on the basis of arginin metabolism. J App/ Bacteriol 23, 3752

Young JM, Dye DW, Bradbury JF, Panagopoulos CG, Robbs CF (1978) A proposed nomenclature and classification for plant pathogenic bacteria. NZJ Agric Res 21, 153-177

Zherebilo OE, Gvozdjak RI (1976) On detecting aminoacid decarboxylases in bacteria of the genus Erwinia. Mikrobiol Zh 38, 293-298 